\title{
Tożsamościowe (trans) lokacje bohaterów prozy Virginii Despentes na przykładzie powieści Apocalypse bébé
}

Artykuł stanowi próbę prześledzenia twórczości współczesnej, trzeciofalowej, francuskiej powieściopisarki, Virginii Despentes, ze szczególnym uwzględnieniem zachodzących w niej na przestrzeni ubiegłych dwudziestu lat zmian. W pierwszej części przedstawiony zostaje zarys wczesnego etapu jej pisarstwa. Na pierwszy plan wysuwają się specyficzne dla kultury francuskiej końca ubiegłego stulecia kwestie kontekstualne: zwłaszcza zachodzących w relacji do rekonfiguracji francuskiego pola literackiego w połowie lat dziewięćdziesiątych przemian w strategii (samo)reprezentacji podmiotów wykluczonych z uwagi na ich rasowo-płciowo -klasowe usytuowanie, oraz wyłonienia się nurtu literatury opatrzonej mianem „trashowej”.

Druga część stawia sobie za cel wydobycie queerowego aspektu ostatniego projektu Despentes. Przeprowadzona w oparciu o geopoetologiczne instrumentarium analiza utworu Apocalypse bébé dostarcza informacji na temat czasoprzestrzennych uwarunkowań (nie)normatywnych tożsamości głównych bohaterów. Autorska konstrukcja miejskiego chronotopu Paryża i Barcelony zestawiona zostaje z propozycjami badaczy kultury spod znaku krytycznych teorii queer, prowadząc do tezy o specyficznym ,zwrocie utopijnym” zachodzącym w ostatniej powieści tej pisarki.

Słowa kluczowe: literatura trashowa, krytyczne teorie queer, seksualność i przestrzeń, trzecia fala feminizmu we Francji, badania miejskie, powieść miejska, geopoetyka 


\section{Riot Grrrl, czyli buntowniczka wkracza na literackie salony}

„Il faut faire éclater les choses."

Pisarski debiut Virginie Despentes (ur. 1969), przypadający na lata dziewięćdziesiąte ubiegłego wieku, zbiegł się w czasie z nową falą francuskiej „literatury kobiecej”2. Przywoływana przez krytyków w kontekście twórczości autorek takich jak Christine Angot, Marie Darrieussecq, Catherine Millet, Marie NDiaye etykieta posłużyła za narzędzie klasyfikacji i swego rodzaju pacyfikacji politycznego wydźwięku literatury spod znaku późnodwudziestowiecznej prozy. Redukcjonizm takiego posunięcia polegał na przypisaniu implicytnych nawiązań do haseł maja 1968 roku szeregowi pisarek, dla których jedynymi punktami wspólnymi był ich płeć oraz odważne traktowanie tematyki seksualnej. Na tle indywidualistycznie zorientowanych autofikcji Angot i Millet oraz przykładów brawurowej fantastyki Darrieussecq i NDiaye prozę fabularną Despentes wyróżniała jednak świeżość spojrzenia towarzysząca projektowi reprezentacji sytuacji zwykle kobiecych podmiotów zmarginalizowanych oraz wykluczonych: typowych prekariuszek wyjętych poza nawias zarówno medialnej, jak i literackiej, widzialności. Świat przedstawiony jej wczesnych powieści budowany był zresztą głównie na oglądzie sytuacji bohaterek nieposiadających ani wykształcenia, ani innych form kapitału poza własnym ciałem: striptizerek, prostytutek, narkomanek, dziewczyn i kobiet pozbawionych szerszych życiowych perspektyw, a równocześnie silnie zdeterminowanych, aby nie pełnić tradycyjnie przypisanych ich płci ról społecznych.

1 Zob. F. Armanet, B. Valloeys, Catherine Breillat, Virginie Despentes: Le sexe à cru, „Libération” 13 lipca 2000, s. 28-30: ,Trzeba to wszystko rozsadzič” [wszystkie zawarte w tekście przekłady pochodzą od autorki - CZ].

2 Zob. G. Bridet, Le Corps à l'ouvre des femmes écrivains: Autour de Christine Angot, Marie Darrieussecq, Virginie Despentes et Catherine Millet, [w:] Le roman francais au tournant du XXIe siècle, red. B. Blanckeman, A. Mura-Brunel, M. Dambre, Paris 2004.

Znacznie trafniej, jak sądzę, umiejscowiła twórczość Despentes krytyka anglosaska, widząc w niej jedną z czołowych reprezentantek francuskiej trzeciej fali feminizmu, rozumianego nie jako postfeminizm, a właśnie radykalizacja, pogłębienie postulatów drugofalowych.

Zob. M. A. Schaal, Virginie Despentes or a French Third Wave of Feminism?, [w:] Cherchez la femme: Women and Values in the Francophone World, red. A. Angelo, E. Fülöp, Newcastle 2011; Third Wave Feminism: A Critical Exploration, red. S. Gillis, G. Howie, R. Munford, New York 2007; Interrogating Postfeminism: Gender and the Politics of Popular Culture, red. Y. Taster, D. Negra, Durham-London 2007. 
Warto wspomnieć, że zarówno głos, jak i styl wczesnej Despentes odznaczał się podwójnym umocowaniem, które uznano za formę legitymizacji: łączył on w sobie dogłębną znajomość określonych kodów gatunkowych $\mathrm{z}$ dopominaniem się o prawo do zaistnienia w publicznym dyskursie dla tych, z którymi autorka dzieliła niegdyś życiowe doświadczenia. W istocie, swój bez mała antropologiczny warsztat przyszła pisarka szlifowała, pracując w młodości w opisywanej później przez siebie branży - obsługując ,,różową” linię telefoniczną oraz zajmując się krytyką filmów pornograficznych. Bezpośredni wgląd w przemysł seksualny pozwolił jej bezlitośnie obnażać jego kulisy przy równoczesnej afirmacji samej seksualności we wszystkich, także nienormatywnych czy wręcz transgresyjnych jej wymiarach. Dlatego właśnie we wczesnym okresie twórczości zbyt łatwo utożsamiano autorkę z bohaterkami jej własnej prozy. Podobnie do nich miała być jedynie gniewną, punkową ${ }^{3}$ dziewczyną znikąd, ze sporem bagażem nieprzyjemnych przeżyć i ostrym językiem służącym za narzędzie samoobrony oraz ataku ${ }^{4}$.

$\mathrm{Na}$ przełomie ubiegłego tysiąclecia kontrowersję w rodzimym środowisku feministycznym wywołała filmowa adaptacja debiutanckiej powieści Despentes: wydanej we Francji w 1993 roku, a przeniesionej na ekran siedem lat później i przedstawionej pod polskim tytułem jako Gwatt (Baise-Moi). Kwestie strategicznego doboru tytułów w wersji oryginalnej oraz niefortunnych, a jednak znamiennych, decyzji translatorskich są zresztą, jak sądzę, do tego stopnia znaczące, że należy poświęcić im więcej uwagi. Przede wszystkim dlatego, że stanowią jeden z ważniejszych wyróżników odautorskiej poetyki/polityki, która nosi wszelkie znamiona na wskroś queerowej taktyki literackiej5.

Przyjęta przez polskich tłumaczy lub dystrybutorów rzeczownikowa forma wymazuje ten aspekt, tymczasem zawarty w oryginale tryb rozkazujący (pol. rżnij mnie) modyfikuje oczekiwania odbiorcy względem podziału ról w zawierającym silny komponent przemocy lub właśnie do niej się sprowadzającym akcie seksualnym. Zwłaszcza że podział na oprawcę i ofiarę ulega w tym wypadku daleko posuniętej problematyzacji: ta ostatnia nigdy nie jest zupełnie bezbronna, ponieważ nie zostaje całkowicie odarta ze swojej sprawczości. W ostatniej instancji

3 Zob. C. Bourseiller, Génération chaos: Punk, New Wave 1975-1981, Paris 2008.

4 Zob. M.A. Schaal, Une nécessaire rébellion feministe: De la violence au féminin chez Virginie Despentes, [w:] Rebelles et criminelles chez les écrivaine d'expression française, red. F. Chevillot, C. Tront, New York 2013.

5 Zob. M. de Certeau, Wynaleźć codzienność: Sztuki dziatania, tłum. K Thiel-Jańczuk, Kraków 2008. 
pozostaje jej jeszcze język, czyli owe - jakby to ujęła Judith Butler, której pisma wywarły silny wpływ na poglądy Despentes - walczące słowa ${ }^{6}$. Zarówno groźba, obietnica, jak i rzucone napastnikowi wyzwanie mają charakter perlokucyjnych performatywów noszących w sobie możliwość nieoczekiwanego oporu. Bohaterki prozy Despentes adaptują takie sposoby działania słowem, że czytelnik zmuszony jest uświadomić sobie ową konstytutywną odwracalność pozycji ustanawiającą wszelkie formy upodmiotowienia w języku. Stąd także dalece znamienny dobór tytułów, który można odczytać jako próbę subwersywnego przechwycenia obelgi - dzieje się tak, między innymi, w powieści Les Chiennes savantes (pol. mądre suki) ${ }^{7}$. Jednym słowem, antycypacyjny akt werbalnej przemocy pozwala bohaterkom odzyskać sprawczość w sytuacji, w której są jej na różne sposoby pozbawiane.

Należy podkreślić, że odsłanianą w utworach Despentes mikrofizykę władzy charakteryzuje nieodmiennie relacyjność, a także intersekcjonalność jej poszczególnych aspektów ${ }^{8}$. Powtarzające się akty agresji lub/i dominacja na tle klasowo-płciowo-rasowym zazębiają się, współtworząc podrzędne, jednak nie w pełni podporządkowane, usytuowanie wykluczanych podmiotów ${ }^{9}$. Marginalizacja społeczna przybiera nadto ukonkretnioną przestrzennie postać: większość bohaterek po prostu pochodzi z i funkcjonuje na co dzień w obrębie przedmieść, a konkretnie zdewastowanych, podmiejskich blokowisk (fr. banlieues), które za sprawą katastrofalnej w skutkach, segregacjonistycznej polityki miejskiej sukcesywnych rządów przemieniły się w nieomal zamknięte getta dla mieszkańców o emigranckich korzeniach, przedstawicieli tzw. widzialnych mniejszości etnicznych ${ }^{10}$.

$\mathrm{Z}$ powodu tak zarysowanego społecznego usytuowania fabuły proza Despentes przypisywana bywała niekiedy do nurtu, który w połowie ostatniej dekady ubiegłego wieku rzucił nowe światło na realia współżycia we współczesnych francuskich metropoliach. Warto w tym miejscu

6 Zob. J. Butler, Walczace stowa: Mowa nienawiści i polityka performatywu, tłum. A. Ostolski, Warszawa 2010.

7 Jest to także intertekstualne nawiązanie do sztuki autorstwa Moliera, Femmes savantes.

8 Zob. Teorie wywrotowe: Antologia przektadów, red. A Gajewska, tłum. A. Grzemska, M. Wesołowska, Poznań 2012.

9 Zob. b. hooks, Teoria feministyczna: Od marginesu do centrum, tłum. E. Majewska, Warszawa 2013.

10 Zob. L. Wacquant, Urban Outcasts: A Comparative Sociology of Advanced Marginality, Cambridge 2008. Zgodnie z obowiązującym dyskursem władzy chodzi o przedstawicieli tzw. minorités visibles. 
przywołać chociażby głośny film Mathieu Kassovitza z 1995 roku pod wiele mówiącym tytułem Nienawiść. Zachodzący wówczas przełom polegał na wyłonieniu się zupełnie nowego stylu filmowej i literackiej reprezentacji zagadnienia: bodaj po raz pierwszy w historii francuskiego pola produkcji kulturowej ${ }^{11}$, mieszkańcy ,,nieuprzywilejowanych przedmieść"12 stali się głównym bohaterami, a zarazem narratorami opowieści. To właśnie ich wewnętrzna perspektywa miała sterować uwagą odbiorcy - by odnieść się do teorii Pierre’a Bourdieu - prawomocnej kultury. Był on zmuszony przyjrzeć się własnemu uprzywilejowaniu niczym w krzywym zwierciadle. Określenie ,,nowy realizm” w odniesieniu do powieści Despentes wydaje się mimo wszystko mało celne, szczególnie ze względu na specyfikę zastosowanych w nich poetyk.

Pisarka odwołuje się bowiem do kodów gatunków popularnych, zwłaszcza tych adresowanych (tradycyjnie) do męskiego odbiorcy: nurtu noir oraz twardej pornografii, jednak nieodmiennie modyfikuje skorelowany z nimi przekaz. Rozsadza je niejako od wewnątrz, wyzyskując do tego celu ich własne instrumentarium. Zabieg ten polega na wprowadzaniu w kadr elementów spoza diegezy, które skutecznie zakłócają proces czysto użytkowego odbioru i towarzyszącej mu przyjemności, zmuszając do krytycznego namysłu. Między innymi temu celowi służyć ma także ukazywanie kulis przemysłu seksualnego w jego wymiarze ekonomicznym, czyli właśnie jako pracy, oraz dokonywana w oparciu o transgresyjne podejście do różnych form cielesnego tabu (abject, masturbacja, zaburzenia żywieniowe, afirmatywny stosunek względem wszelkiego rodzaju wydzielin) ${ }^{13}$ dekonstrukcja przedstawień kobiecości głównego nurtu.

Konsekwentnie wyzyskiwany tryb popkulturowego zapośredniczenia prowadzi również do przechwycenia strategii charakteryzujących umasowione produkty przemysłu rozrywkowego: filmy klasy B, niewymagające komiksy, seriale czy teledyski. Rzekomo realistyczny styl w istocie

11 Zob. P. Bourdieu, Reguty sztuki: Geneza i struktura pola literackiego, tłum. A. Zawadzki, Kraków 2001.

12 Warto odnotować, że francuski dyskurs publiczny służący do opisu (de facto performatywnego umniejszania), ,problemu przedmieśc” opiera się na strategii stosowania eufemizmów. Mowa jest bowiem właśnie o przedmieściu „,nieuprzywilejowanym” (fr. banlieue défavorisée) lub o ,wrażliwych strefach miejskich” (fr. zones urbaines sensebiles). W tym kontekście stosowaną przez Despentes taktykę hiperboli uznać można za literacką próbę stworzenia kontrdyskursu wobec dyskursu władzy.

13 Zob. S. Jordan, Dans le mauvais goût pour le mauvais goût?: Pornographie, violence et sexualité féminine dans la fiction de Virginie Despentes, [w:] Nouvelle écrivaines: Nouvelles voix, red. N. Morello, C. Rodgers, New York 2002. 
zaskakująco łatwo ociera się o przesadę oraz osuwa w parodię, zaś sylwetki, szczególnie męskich postaci, pisane są grubą kreską. W powieściach Despentes następuje odwrócenie uprzedmiotawiającego spojrzenia. Dystrybucja ról pozostaje wyraźnie stronnicza, gdyż zastosowanie konwencji opartej na zasadzie ekscesu i nadmiaru służyć ma uwidacznianiu zachodzących relacji władzy. Podobną funkcję pełni zabieg przejęcia przez bohaterki ,,męsko” nacechowanych rekwizytów - choćby rewolweru jako narzędzia gwałtu i vendetty w Baise-moi. Z uwagi na poruszaną problematykę, punkowy kontekst kulturowy, z którego wywodzi się autorka, a zwłaszcza specyficzny dobór stosowanych przez nią strategii narracyjnych, bardziej odpowiednim wydaje mi się dostrzeżenie pokrewieństwa poetyki Despentes z nurtem literatury trashowej ${ }^{14}$.

Powyższe spostrzeżenia odnoszą się przede wszystkim do wczesnych utworów pisarki, którym zarzucano bezalternatywność wynikającą z pośrednio stawianej przez nią diagnozy społecznej. Tymczasem, po dwudziestoletniej obecności we francuskim polu literackim, wydaniu łącznie sześciu powieści ${ }^{15}$, zbioru nowel (Mordre au travers), manifestu w formie eseju autobiograficznego(King Kong Théorie), komiksu (Trois étoiles), a także nakręceniu filmu dokumentalnego (Mutantes) oraz wyreżyserowaniu pełnometrażowych fabuł na podstawie własnej prozy (Baise-moi i Bye Bye Blondie), twórczość jej, jak sądzę, uległa w tym aspekcie szeregowi wartych dostrzeżenia zmian. Nie chodziłoby jednak o zatarcie początkowej siły buntu i niezgody na zastaną rzeczywistość, lecz uzupełnienie wymiaru kontestacyjnego elementem afirmatywnym noszącym pewne znamiona queerowej utopijności.

\section{Cruising utopia, czyli kilka uwag na temat ostatniej powieści Virginie Despentes}

Proponuję zatem przyjrzeć się najnowszej propozycji Despentes, powieści Apocalypse bébé, pod kątem relacji zachodzących pomiędzy przestrzennym usytuowaniem bohaterów oraz ich (nie)normatywną tożsamością. Utwór ten czerpie bowiem zarówno z konwencji powieści detektywistycznej, romansu lesbijskiego, jak i ostrej satyry społecznej. Szczególnie interesująco wypadają w nim wątki otwierane przez temat typowy dla powieści

14 Tookreślenieodsyłarównocześniedokonkretnejseriiwydawniczej, wskazuje na status bohaterów - wyrzutków neoliberalnego społeczeństwa - oraz nazywa typ produkcji kulturowej, której są oni konsumentami.

15 Kolejno: Baise-moi (1993), Les Chiennes savantes (1996), Les Jolies Choses (1998), Teen Spirit (2002), Bye Bye Blondie (2004) i Apocalypse bébé (2010). 
miejskiej z elementami powieści drogi. Otóż, pierwszo- oraz trzecioosobowa ${ }^{16}$ narracja zakreśla szeroki przegląd ponowoczesnych tożsamości określanych w dużej mierze poprzez przestrzenne usytuowanie poszczególnych postaci. Znajdziemy wśród nich: zagubioną nastolatkę, nuworyszkę-ekspatriantkę, należącego do burżuazji konserwatywnego pisarza i jego żonę, podstarzałą detektywkę-przedstawicielkę prekariatu oraz jej charyzmatyczną współpracownicę, wykluczonego nastolatka z przedmieść. Tożsamość bohaterów wiąże się z ich odmiennym statusem społecznym związanym również z silnie zróżnicowanym typem przynależności do hierarchicznie wartościowanej przestrzeni miejskiej. Szlak śledczych poszukiwań oprowadza czytelnika między innymi po paryskich mieszkaniach przedstawicieli wyższej klasy średniej, niezgentryfikowanych dzielnicach nocnego życia, podparyskich osiedlach, barcelońskich strefach rezydencjalnych, aż po alternatywne i efemeryczne przestrzenie kreowane przez queerowe wspólnoty. Projekt powieściowy opiera się na kompozycyjnej zasadzie nieoczywistych zestawień przedstawicieli skonfliktowanych środowisk, nagłych spotkań nieprzystających od siebie postaci oraz ich wzajemnej interferencji.

W tym kontekście za warte uwagi uznać można pojemne definicje odmieńczości zaproponowane przez przedstawicieli krytycznych teorii queer - Judith Halberstam, José Estebana Muñoza i Beatrice Preciado - oraz koncepcje geopoetologiczne ujmujące obszar metropolitalnej miejskości jako agon, na którym rozgrywają się charakterystyczne również dla współczesnej Francji konflikty socjokulturowe ${ }^{17}$. Na główny plan wysunie się zatem kilka kluczowych kwestii: związku miejsc urodzenia i zamieszkania z pochodzeniem oraz poczuciem kulturowo-etniczno-płciowo-klasowej przynależności głównych bohaterów, trybu i sposobu przemieszczania się, celu, motywacji, a także rezultatu ewentualnej mobilności, wyrażanego przez nich wprost lub tylko implikowanego stosunku względem zajmowanego przez siebie miejsca lub, w wypadku nomadyzmu, miejsc. Jednym słowem, chodzić będzie o krytyczną rekonstrukcję oraz interpretację itinerariów rozumianych jako heterogeniczne szeregi kolejnych przestrzenno-tożsamościowych przesunięć i przekroczeń dokonywanych przez głównych bohaterów.

16 Chodzi o tzw. mnogą fokalizację, czyli różnorodne zogniskowanie narracji. Zob G. Genette, Figures III, Paris 1972.

17 Zob. Space and Place: Theories of Identity and Location, red. E. Carter, J. Donald, J. Squires, London 1993, D. Harvey, Paris, capitale de la modernité, Paris 2012; tegoż, Bunt miast: Prawo do miasta i miejska rewolucja, tłum. A. Kowalczyk, W. Marzec, M. Mikulewicz, M. Szlinder, Warszawa 2012. 


\section{Normatywny cykl i kadr życia: Claire i François}

Na początek przyjrzyjmy się pierwszej grupie postaci: dobrze sytuowanym przedstawicielom metropolitalnej wyższej klasy średniej. François (ojciec zaginionej nastolatki imieniem Valentine) oraz Claire (jego obecna żona) mieszkają w prestiżowej, szesnastej dzielnicy Paryża (w powszechnym uzusie językowym dzielnice te określane są nawet mianem ,złotych”), prowadzą zasadniczo stacjonarny tryb życia, nigdy też nie zmienili swojej lokalizacji. Nie dowiadujemy się niczego o ich podróżach ani sposobie przemieszczania się po mieście (bohaterowie uznają te informacje za nieistotne, skoro nie służą one samookreśleniu). Ich adres zamieszkania oznacza bowiem dystynkcję, przesądza o przynależności do grupy społecznie uprzywilejowanej. François jest z zawodu pisarzem, de facto rentierem, spadkobiercą rodzinnego majątku (jako syn obrotnego przedsiębiorcy, który odniósł sukces w przemyśle, należy do burżuazji), jego trzecia żona zajmuje się prowadzeniem domu oraz wychowywaniem córek z wcześniejszego małżeństwa. Samoocena Claire uwarunkowana została przez patriarchalne spojrzenie obrócone przeciwko niej samej: mierzy swoją wartość w odniesieniu do rynku matrymonialnego, zaś gwarancję dobrego samopoczucia stanowi dla niej możliwość umieszczenia się ,,powyżej” na jego skali: ,,Jedynymi kobietami, które potrafiła teraz znieść, były samotne i bezdzietne znajome w jej wieku. Były to jedyne kobiety, które usytuować mogła poniżej siebie, a więc również widywać bez obawy, że porównanie wypadłoby na jej niekorzyść" 18 .

W obrębie habitusu, który nabyła w procesie wczesnej socjalizacji, uległość, a także fasadowa grzeczność pozwalają Claire zaznaczyć swoją pozycję, w odczuciu innych bohaterów stanowią natomiast czytelny przejaw poczucia wyższości klasowej. Podobną, onieśmielającą rolę pełni luksusowy wystrój apartamentu i jego wielkość: „,François wskazuje fotel Miesa van der Rohe w przedpokoju. »Proszę usiąść tutaj, jeśli to Panu odpowiada« i ściska mu dłoń w podziękowaniu: sposób na zakomunikowanie, że nie ma powodu, dla którego miałby przeszkodzić im, kiedy skończy" ${ }^{19}$. Zresztą nie tylko życiowa przestrzeń charakteryzuje usytuowanie bohaterów, także ich stosunek względem czasu pozostaje w ścisłym, nierozłącznym związku z logiką produktywności, bezpośrednio przekładając się na zajmowaną wobec innych postawę: „ZZ głębi przedpokoju pomoc domowa uprzedza, że skończyła już prasowanie i zaraz wychodzi. [François - przyp. CZ] Rzuca okiem na swój zegarek,

18 V. Despentes, Apocalypse bébé, Paris 2010, s. 85.

19 Tamże, s. 52. 
za dwadzieścia dwunasta. Oczywiście, policzy sobie za pełną godzinę"20.

Gdy tylko trafia do tej przestrzeni, prowadząca śledztwo Luce stwierdza, że: ,Mieszkanie od razu mnie zaatakowało. Zbyt duże, zbyt czyste, zbyt drogie" ${ }^{21}$, natomiast Yacine, kuzyn zaginionej Valentine, mieszkaniec podmiejskiego getta, łączy postawę dziewczyny z miejscem, w którym została ona wychowana: ,,jasne, mieszka w centrum miasta, traktują ją jak księżniczkę, chodzi do miejsc dla bogaczy, jada tylko markowe żarcie podane na porcelanie [...]. Z tymi dwustoma metrami kwadratowymi w samym centrum, sam jej pokój, większy od ich mieszkania [...]"22.

Zarówno lokalizacja, jak i metraż mieszkania wskazują pośrednio na proces reprodukcji nierówności społecznych oraz istniejących podziałów na tle klasowym. Co istotne, astronomicznie wysokie ceny mieszkań we francuskiej stolicy sprawiają, że blisko dziewięć dziesiątych ogólnej liczby jego mieszkańców to lokatorzy. Wyłom od tej zasady stanowi sytuacja przedstawicieli grup uprzywilejowanych, dziedziczących prawa własności. Nawiązanie do tej kwestii stanowią bezlitośnie ironizujące słowa Vanessy (pierwszej żony François, córki maghrebskich emigrantów, która postanowiła przekroczyć swoje wyjściowe położenie, wykorzystując do tego celu własną atrakcyjność seksualną), oceniające status majątkowy niedoszłego kochanka - świeżej daty celebryty:

Wychowany w przestronnych domach prestiżowych dzielnic, uczęszczał do najlepszych szkół zanim zorientował się, że nie starczy mu siły charakteru, aby kontynuować tradycję rodzinnego sukcesu. Ogłosił się artystą i radykałem, a następnie zdecydował się żyć z tego, co miesiąc w miesiąc przelewa na jego konto tatuś [...]. Lubi zgniłe dzielnice, bo może w nich poczuć swoją wyższość i wie, że się z nich wyniesie, kiedy tylko zechce. Wystarczy, żeby zmienił zdanie. Kiedy będzie mieć dość tego, że jego dzieci mijają dziwki pod domem, klucze od mieszkań odziedziczonych w rodzinnym spadku znajdą się w jego rękach. W międzyczasie miałkość swojego charakteru prezentuje jako subwersywny wybór ${ }^{23}$.

Odnotujmy, że według Halberstam queerowość oznacza przede wszystkim opozycyjność wobec trzech podstawowych zinstytucjonalizowanych nakazów normatywnie strukturyzujących życie jednostek. Po pierwsze, przynależności do/założenia własnej, tradycyjnej (nuklearnej) rodziny,
20 Tamże, s. 47.
21 Tamże, s. 102.
22 Tamże, s. 140-141.
23 Tamże, s. 165. 
po drugie heteroseksualności, po trzecie reprodukcji ${ }^{24}$. Za odmieńcze uznaje zatem takie sposoby życia, a także typy relacji, które nie rozgrywałaby się w obrębie paradygmatycznych wyróżników kolejnych jego etapów wyznaczanych przez sukcesywne, usankcjonowane rytuały przejścia takie jak: narodziny, ślub, przyjście na świat potomstwa, śmierć. Autorka argumentuje, że w nowoczesnej historii kultury Zachodu kluczową rolę odgrywa idea stabilizacji, dążenia do długowieczności, uprzywilejowania okresów długiego trwania zabezpieczających przyszłość zarówno jednostki, rodziny, jak i pokoleń czy wręcz całego społeczeństwa: chodziłoby o zachowanie homologii. Cykl życia nienormatywnych podmiotów, przeciwnie, cechuje konstytutywna nielinearność. Wyakcentowaniu ulega w nim to, co płynne, kontyngentne, umykające, podlegające różnego rodzaju, niekiedy gwałtownym, zerwaniom (ze szczególną rolą kryzysów w etymologicznym tego słowa znaczeniu). Natomiast alternatywny chronotop opiera się na dowartościowaniu doświadczenia nieustającej i nieustępliwej teraźniejszości, a nawet jego celowej intensyfikacji (wątek ten rozwija w swojej pracy poświęconej queerowej utopii Muñoz, nawiązując do koncepcji Ernsta Blocha).

Jednak François oraz Claire wcale nie zmieniają swojej lokalizacji, ponieważ służy im ona do potwierdzeniu własnego statusu klasowego. Ich życie rozgrywa się właśnie w ściśle określonych, przyszłościowo i na wskroś produktywnie zorientowanych ramach. Stanowi zatem rewers wszelkiej formy kontestacyjnej odmieńczości.

\section{Queerowe bycie w poprzek i wielopozycyjność: Luce i Hiena}

Postacie o tożsamości na różne sposoby wykraczającej poza normę reprezentują całkowicie odrębny typ bohaterów. Cechująca je queerowość nie musi oznaczać frontalnej opozycyjności, może również wyrażać się poprzez swoistą oboczność: bycie w poprzek, obok, równocześnie. Termin wielopozycyjność, odsyłający do nieredukowalnie mnogich, nierzadko heterogenicznych podmiotowych usytuowań, okazuje się tu kluczowy. Trafnie relacjonuje on sytuację (a właściwie ewolucję) odpowiedzialnej za prowadzenie części narracji Luce. Odnotujmy, że Despentes po raz kolejny zdecydowała się na typowy dla siebie zabieg przedstawienia opisywanej rzeczywistość z perspektywy postaci zmarginalizowanej, to znaczy protagonistki, która samą siebie postrzega jako przegraną w wyścigu

24 Zob. J. Halberstam, In a Queer Time and Place: Transgender Bodies, Subcultural Lives, New York 2005. 
o sukces mierzonym neoliberalnymi, ale i egzystencjalnym kryteriami: „Jestem źle opłacaną lamerką, która właśnie dała sobie wcisnąć dwa tygodnie roboty w ukryciu, żeby dopilnować wiecznie zjaranej, nadaktywnej nastoletniej nimfomanki" ${ }^{25}$ - narzeka. Luce postrzega samą siebie ze znamienną mieszanką autoironii oraz gorzkiego poczucia humoru desperatki: „Dlaczego niby mieliby pozbawić się przyjemności terroryzowania swego bliźniego, skoro jestem tutaj, do dyspozycji, na samym dole piramidy?"26 - dopytuje ironicznie.

Obrana perspektywa pozwala drobiazgowo przedstawić rozmaite relacje władzy (zwłaszcza dominacji), na które ta bohaterka jest szczególnie wyczulona, zapowiada również jej otwartość na potencjalne zmiany (tym większą, że Luce w zasadzie ,,nie ma niczego do stracenia”). O podrzędnej pozycji prekariuszki świadczy rodzaj zajmowanej przez nią przestrzeni: wychowała się na prowincji, w rolniczej części Francji, a w stolicy zamieszkuje wyłącznie kawalerki - obecnie w okolicach przystan$\mathrm{ku}$ metra Bellville (dzielnica o robotniczym rodowodzie). Pracuje w ciasnych, niewietrzonych pomieszczeniach biurowych, po mieście porusza się wyłącznie korzystając z środków publicznego transportu. Warto zwrócić uwagę na semantykę ,,zamknięcia”, to ona wpływa na przeciwstawne - negatywne w wypadku Paryża i entuzjastyczne, jeśli chodzi o Barcelonę - wartościowanie doświadczenia miejskiego ${ }^{27}$.

Za najbardziej nienormatywną ze wszystkich postaci uznać wypada Hienę: detektywkę, lesbijkę i wolnego strzelca: ,,ona była nie do odzyskania, niezdolna do normalnego życia. [...] Nie przeszkadzało jej odgrywać rolę lesby rodem z wyobrażeń heteryków: brutalnej, zmarginalizowanej i gotowej uciąć fiuta komu popadnie" ${ }^{28}$. W społecznej tkance miasta realizuje ona funkcję naruszającej istniejące podziały tricksterki. Ponieważ zajmując się dystrybucją narkotyków, a następnie pracując dla służb wywiadu, poznała miasto od podszewki, płynnie porusza się pomiędzy różnymi jego obszarami i z łatwością reaguję na zmiany kontekstu sytuacyjnego:

Koniec z dzielnicami pełnymi zatłoczonych ulic, zadymionych barów wypchanych dziwkami czy narkomanami, koniec z zamieszkanymi podziemiami w stanie dewastacji, kuchniami śmierdzącymi tłuszczem i lewymi pokojami. Teraz kursowała wyłącznie w dzielnicach z licznymi bankami i rezydencjami ${ }^{29}$.

25 V. Despentes, Apocalypse..., s. 16

26 Tamże, s. 15.

27 Zob. Yi-Fu Tuan, Topophilia: A Study of Environmental Perception, Attitudes and Values, Englewood Cliffs 1974.

28 Tamże, s. 28, 243.

29 Tamże, s. 248. 
Potrafi ponadto cyrkulować pomiędzy różnymi środowiskami i odgrywać wiele ról, dzięki czemu jej tożsamość wymyka się jasnym podziałom klasyfikacyjnym: prezentuje tym samym alternatywny typ postawy wobec siły konwencji. O ile bowiem bohaterowie o normatywnej tożsamości odtwarzają swoje role w sposób powtórzeniowy - za Ervingiem Goffmanem powiedzielibyśmy, że ich działaniom przyświeca chęć kontroli i kodyfikacji własnych zachowań, tak na scenie, jak za kulisami ${ }^{30}$ - o tyle Hiena odgrywa poszczególne z nich w sposób zasadniczo nieciągły, uniewiarygodniając performowaną przez innych fikcję spójności (z tego źródła bierze się także opór bohaterki wobec urządzeń kontroli i przestrzeni wymuszających normatywizację jednostki, na przykład lotnisk - Hiena najlepiej czuje się w drodze). Popada przy tym w niejaką przesadę, a nawet karykaturę tożsamości rozumianej jako autoidentyfikacja dokonywana w oparciu o własne, mniejszościowe preferencje seksualne:

Trąbią za nami jacyś kretyni. Przez ulicę przechodzą trzy młode dziewczyny. Paryżanki w wersji niskobudżetowej. Szczupłe, długonogie, w modnych, futrzanych botkach, cycate, z nieodzowną grzywką. Tanie kopie autentycznych suk z Marais, tych, które kiedy pójdą w totalnie dziwkarską stylówę, przywodzą na myśl reklamę perfum, a nie podmiejskie tirówki.

Hiena wychyla głowę przez okno i gwiżdże na nie z podziwem. [...] Gestem kciuka daje im do zrozumienia, że są zajebiste, ocenę wzmacnia dodatkowym wykrzyknieniem:

- Hej, dziewczyny, ale z was dobre dupy ${ }^{31}$ !

Przytoczona scena, co znamienne, rozgrywa się w przestrzeni miejskiej i dotyka kwestii upłciowienia ról przypadających w udziale uczestnikom ruch drogowego: jako kierowca Hiena wykorzystuje swoją przewagę względem przechodzących dziewczyn, zachowuje się niczym rozrabiaka, który rości sobie prawa do seksistowskich komentarzy. Z wywiązującego się pomiędzy Luce oraz Hieną dialogu wynika, że zachowanie to jest przejawem celowego ,naginania” normy, czyli uzusu: strategia przesady służy uwypukleniu form werbalnej i/lub symbolicznej przemocy, która uchodzi za oczywistośćc ${ }^{32}$.

30 Zob. E. Goffman, Cztowiek w teatrze życia codziennego, thum. H. Datner-Śpiewak, P. Śpiewak, oprac. J. Szacki, Warszawa 1977.

31 Tamże, s. 59.

32 Zob. D. Massey, Space, Place and Gender, Cambridge 1994. 
Z powyższego fragmentu wyczytać można także ciekawe informacje o związku zachodzącym pomiędzy przynależnością do danej dzielnicy Paryża - w tym wypadku chodzi o Marais - a określonym stylem bycia. Antropologicznie ujmowany styl egzystencji obejmowałby wówczas szereg zachowań, które określane są jako ,,sposoby użytkowania”33, a dotyczą nie tylko mody - ubioru i wizerunku - ale też, między innymi, typu uczestnictwa w określonej przestrzeni miejskiej. Marais - niegdysiejsza dzielnica artystów oraz żydowskiej i homoseksualnej mniejszości, od kilku ostatnich dekad zaś symbol postępującej gentryfikacji centrum - jawi się jako swego rodzaju luksusowy deptak, wymagający specyficznej formy autoprezentacji. Potrzeba chodzenia, spacerowania czy przemieszczania się podporządkowana zostaje chęci ,,pokazania się”, czyli zaprezentowania swej, jak najbardziej utowarowionej, kobiecości/męskości. Jest to model aspiracyjny, do którego napotkane dziewczyny jedynie dążą, w sposób - wedle oceny interpretatorki, czyli Luce - nie w pełni udany. To niefortunne naśladownictwo stawia zarazem problem autentyzmu danej formuły tożsamościowej i jego artykulacji w odniesieniu do materialnego aspektu użytkowanych przedmiotów ${ }^{34}$. Szczególnie silnie wybrzmiewa on w kontekście - reprezentowanych przez ostatni z zarysowanych w powieści typów bohaterów - ponowoczesnych tożsamości hybrydowych: mieszanych lub w różnym stopniu transkulturowych.

Różne warianty tożsamości hybrydowych: Yacine, Vanessa, Valentine

Stwierdzenie, że refleksja nad miastem jest zarazem refleksją nad kulturą rozumianą jako obszar sporu, agonu, a zarazem nieustających negocjacji ${ }^{35}$, nabiera szczególnej wyrazistości w odniesieniu do bohaterów - mieszkańców zmarginalizowanych przedmieść. Za sztandarowy przykład postawy, którą w pewnym uproszczeniu nazwać by można odrzuceniem mitu wielokulturowości ${ }^{36}$, służy sylwetka Yacine’a. Dysponuje

33 Zob. P. Jousset, Anthropologie du style: Propositions, Pessac 2008.

34 Zob. M. Warchała, Autentyczność i nowoczesnośc: Idea autentyczności od Rousseau do Freuda, Kraków 2006.

35 Zob. E. Rybicka, Od poetyki przestrzeni do polityki miejsca: zwrot topograficzny w badaniach literackich, "Teksty Drugie” 2008, nr 4 (112), s. 21-38.

36 Zob. P. Bourdieu, L. Wacquant, Nowomowa neoliberalna, thum. M. Starnawski, „Recykling Idei” 2007, nr 9. 
on językiem gniewu, który jest formą sprawczości w konfrontacji z faktycznymi, wynikającymi z praktyk i zinstytucjonalizowanych polityk dyskryminacyjnych, warunków bytowych, w jakich zmuszony jest żyć. Yacine, czyli niejako zawczasu skazany na społeczną klęskę nastolatek, konieczność przyswojenia sobie habitusu konstytuowanego przez prawomocną kulturę uznaje za formę przemocy pod swoim adresem: „Ale on nie słucha tego, co wygadują w szkole. Tamta kultura nie jest dla niego. Nie można mu tego wcisnać do głowy. Edukacja dla Prawdziwych Francuzów. Jego to nie dotyczy [...]"37. Według Bourdieu instytucje edukacyjne, zwłaszcza szkoła, są jednym z głównych czynników odpowiedzialnych za reprodukcję już istniejących, a za ich sprawą jeszcze pogłębianych nierówności klasowych. Oderwana od swego wymiaru materialnego, prawomocna kultura obraca się w wywołującą nienawiść i wyostrzającą poczucie wykluczenia farsę.

Tożsamość Yacine’a jest co prawda ponowoczesna, ale próżno szukać w jego wypowiedziach czy poczynaniach pochwały etnicznie zróżnicowanej, wielowymiarowej, podmiotowej autointerpretacji, przeciwnie, sytuacja zaostrzonego konfliktu klasowego wymaga ujednoznacznienia swojej pozycji ${ }^{38}$. Skoro akty dyskryminacji opierają się na etykietyzacji i przyszpileniu, to radykalny opór musi, według oceny bohatera, wyrażać się poprzez odmowę wszelkiej negocjacji w zakresie sprzecznych wartości kulturowych: ,,[moja siostra nie ma - przyp. CZ] nic wspólnego z pizdą w chuście w obiegowym wydaniu, tą, którą zakrywa się tylko dla szpanu i zachowuje jak dziwka, ledwo wsiądzie do autobusu. Nowoczesny islam, ta ściema francuskich Arabów" ${ }^{39}$ - pomstuje Yacine. Hybrydyzację uznaje on za przejaw zdrady, szalbierstwo czy kolaborację. Przeciwstawieniu ulegają przestrzeń ,,własna” (dom, blokowisko) i publiczna (środki transportu), w której dochodzi do ,europeizacji” obyczajów francuskich muzułmanów. Formą walki jest w tym wypadku celowe wywoływanie kryzysu, jego potęgowanie: ,Już tylko najbardziej kłamliwi Francuzi mogą wmawiać sobie, że porozumienie jest jeszcze możliwe. Ci, którzy nigdy nie widzieli tych szczurów. Tego jak żyją, tego gdzie żyją" ${ }^{40}$. Niepoślednią rolę odgrywają warunki bytowe w ich materialnym wymiarze: ,,Kryzys. Jaki kryzys. On w całym swoim życiu nie zaznał niczego innego. [...] To jak asfalt otaczający ich z każdej strony. Dotykalny, nie-do-przekroczenia, wszyscy mają w nosie,

\footnotetext{
37 V. Despentes, Apocalypse..., s. 135.

38 Zob. Dylematy wielokulturowości, red. W. Kalaga, Kraków 2004.

39 V. Despentes, Apocalypse..., s. 137.

40 Tamże, s. 138.
} 
czy im się podoba, czy nie. Jest jakiś porządek" ${ }^{41}$. Asfalt, zdewastowane, zaszczurzone klatki schodowe, to zarówno metafory, jak i materialny konkret współkształtujący zmarginalizowane usytuowanie i domykający uwięzienie sportretowanych mieszkańców banlieus ${ }^{42}$.

$\mathrm{Z}$ pozoru pokrewne kwestie prezentują się jednak odmiennie w wypadku Valentine, której rodziców różni zarówno pochodzenie klasowe, jak i et-niczne. Jeśli bowiem Yacine hipostazuje własną odmienność, podnosząc ją do rangi zasady regulatywnej i antyasymilacjonistycznego etosu, to dziewczyna zdaje się zupełnie ignorować jej istnienie: „Aż do teraz wzorowała się w swoim zachowaniu na ojcu: nie miała podwójnych korzeni. Nie miała rozpoznawalnej urody, była ciemną brunetką. Jej skóra nie ciemniała pod wpływem pierwszych promieni słońca, dobrze się opalała” ${ }^{3}$. Valentine powinna była poprzestać na wyznaczonych jej (odpowiednich dla jej statusu) rewirach miasta: ,,Szkoła znajduje się na nadbrzeżnym bulwarze Sekwany, w jednej z tych biurowych dzielnic pełnych apartamentowców, w których wydaje się do pomyślenia, by ktoś potrzebował kupić sobie bagietkę lub litr mleka" "44, jednak ucieczka z domu wiążę się z szeregiem znamiennych przemieszczeń.

Bohaterka spotyka ludzi, wobec których odczuwała wcześniej pogardę, a za którymi teraz podąża: wszystkie trasy pokonuje piechotą, trafia do nieznanych sobie miejsc (choćby obskurnego baru blisko placu Pigalle i przy Porte de Montreuil, les Halles, alternatywnego skłotu, mieszkania Magali - daleko za Gambetta, czyli miejscem zbiórek młodzieżowych subkultur). Także w Barcelonie, do której przybywa w poszukiwaniu swojej biologicznej matki, pomieszkuje w wielu różnych częściach miasta (w dzielnicach: Poble-sec, la Floresta, parku Oreneta). Nie zmienia to faktu, że: „Gdzie nie spojrzy, dostrzega tylko nieszczęście, niesprawiedliwość i brutalność" ${ }^{45}$, wobec czego poddaje się namowom makiawelicznej siostry zakonnej z Opus Dei, a po powrocie do stolicy dokonuje samobójczego zamachu w jej reprezentacyjnym centrum - Palais-Royal (właśnie dlatego zakończenie powieści interpretować można również na modłę anarchofeministyczna).

41 Tamże, s. 142, 144.

42 Ten sposób obrazowania, przełomowy w latach dziewięćdziesiątych, obrócił się z czasem w kolejną kliszę kulturową. Warto zauważyć, że faktyczny ruch ,odzyskiwania” sprawczości polega dziś częściej na akcentowaniu tych przejawów podmiejskiego życia, które w oczach mieszkańców stanowią o jego samoistnej wartości.

43 V. Despentes, Apocalypse..., s. 293.

44 Tamże, s. 64.

45 Tamże, s. 304. 
Vanessa realizuje natomiast model pośredni, pod wieloma względami transwersalny. Do Barcelony wyjechała z nowym mężem-architektem, by zrealizować swoje marzenie o byciu pełnoprawną Francuzką, identyfikowalną jako mieszkanka stolicy na obczyźnie:

Mieszka w północnej części miasta, na wzgórzu. Dzielnica eleganckich, starych domów [...]. Kilka współczesnych, białych konstrukcji przydaje ulicom pseudokalifornijskiego szyku. [...] Gdyby nadal żyła we Francji, byłaby przekonana, że to z powodu jej rozpoznawalnej urody. Ale tutaj - jest to jeden z powodów dla których chciała przyjechać - nic nie odróżnia jej od miejscowych. Po prostu ubiera się lepiej. Tutaj jest Paryżanką. Nikomu nie zdarza się ukradkowy uśmieszek kiedy mówi, że ma na imię Vanessa ${ }^{46}$.

Choć dzięki pracy nad sobą, determinacji oraz potrzebie mimikry nabyła habitus typowy dla przedstawicieli klasy uprzywilejowanej, w dalszym ciągu czuję się ,,jak imitacja, podróbka”. W efekcie dysponuje de facto zdublowanym pakietem kompetencji kulturowych, o czym dobitnie świadczy poniższa scena, odnosząca się do dwu odmiennych użyć języka:

"Przekaż tylko ode mnie swojemu chujowi-mężulkowi i teściowej-dziwce, że gdyby porządnie wykonywali swoją robotę, do niczego by nie doszło i moja córka spałaby teraz spokojnie w swoim łóżku, zamiast szwendać się gdzieś jak ta ostatnia wywłoka». Dziewięćdziesiąty trzeci w pełnej krasie. Niełatwo było się tego pozbyć, ale kiedy tylko zachodziła taka potrzeba, wszystko wracało do niej w stanie nienaruszonym. A ludność z szesnastej dzielnicy nie nawykła do tego, żeby zwracać się do niej w ten sposób. Wcale im się to nie podoba ${ }^{47}$.

Dziewięćdziesiąty trzecia to numer w publicznym dyskursie uznawanego za najbardziej ,,newralgiczny” departamentu na obrzeżach stolicy, z którego bohaterka się „wyrwała”. Usytuowanie Vanessy pozostaje zatem wielowymiarowe: dzięki uzyskanemu statusowi może pozwolić sobie na postawę wyższościową, a nawet rasistowską (względem swojego nowego otoczenia), jej tożsamość wiąże się równocześnie z dwuznacznym poczuciem przynależności do miejsca urodzenia: pozostaje dziewczyną z Noisy-le-Grand, dla której w sytuacji poczucia zagrożenia ofensywny język okazuje się najskuteczniejszą formą samoobrony.

46 Tamże, s. 168.

47 Tamże, s. 179. 


\section{Zakończenie}

Kompozycja całej powieści przeciwstawia sobie chronotopy Paryża i Barcelony, wskazuje zarazem na różne typy tożsamości (statycznych bądź dynamicznych) związanych z zasadniczo nieprzystającymi do siebie doświadczeniami miejskimi. Jak stwierdza Luce: ,,Kiedy tylko wyjedzie z stolicy, można uświadomić sobie, jak bardzo Paryż jest ponury, głośny, przygnębiający i przeciwny życiu” ${ }^{38}$. Tymczasem Barcelona jawi się w oczach tejże bohaterki jako miejsce wolności oraz radości życia, tym bardziej, że to właśnie tutaj poznaje ona Zośkę - emigrantkę, poliglotkę mieszkająca wcześniej w Paryżu, obecnie w stolicy Katalonii, wybierającą się do Berlina - równocześnie zaś uroki alternatywnej, queerowej wspólnotowości opartej na towarzysko-erotycznej, poliamorycznej wielorelacyjności ${ }^{49}$. Zgorzkniała Luce niespodziewanie zakochuje się w dziewczynie realizującej nomadyczny model tożsamości ${ }^{50}$ i odnajduje w sobie otwartość na dalsze zmiany.

O ile, jak wskazywałby na to uzus językowy, do stolicy Francji należy się wspiąćc ch $^{11}$ by następnie rozpoznać ,,należne sobie” miejsce: ,Juan wylądował w Paryżu przeświadczony, że zrobi karierę - dryl uzdolnionego akademika miał wymazać jego proletariackie pochodzenie. Potrzebował czasu, aby zrozumieć, że ludzie dobrze urodzeni rozpoznają się po zapachu i w podobny sposób wykluczają intruzów" 52 , o tyle Barcelona - dla Luce i Hieny raczej symboliczne i wyobrażone ,gdzie indziej” niźli miejsce realne - otwiera horyzont bliżej niesprecyzowanej utopijności opartej na potrzebie wyobrażenia sobie radykalnie odmiennego projektu społecznego.

Choć spojrzenie głównej narratorki powieści Apocalypse bébé ukierunkowuje ocenę czytelnika, to obraz relacji wyłaniający się w efekcie całościowej lektury ulega daleko większym komplikacjom, niż miało to miejsce w kontekście wczesnej twórczości tej autorki. Tym samym, wymiar kontestacyjny, polegający na ukazywaniu przemocy inherentnej

48 Tamże, s. 154.

49 Zob. J.E. Muñoz, Cruising Utopia: The Then and There of Queer Futurity, New York 2009, E. Freeman, Time Binds: Queer Temporalities, Queer Histories, Durham 2010.

50 Zob. R. Braidotti, Ucieleśnienie i różnica seksualna w feminizmie wspótczesnym, tłum A. Derra, Warszawa 2009.

51 Wyrażenie to odsyła do hierarchiczności struktur władzy państwowej (fr. on monte à la capitale). Topos tego awansu można uznać za jedną z cech konstytutywnych francuskiej powieści nowoczesnej.

52 V. Despentes, Apocalypse..., s. 250. 
dla różnego typu relacji społecznych, wzbogacony zostaje o noszący znamiona queerowej utopijności aspekt afirmatywny. W efekcie zawarta w kreacji literackiej wizja rzeczywistości zachowuje cechującą ją nieodmiennie potrzebę wyrażenia sprzeciwu wobec neoliberalno-patriarchalnego porządku, jednak, być może po raz pierwszy, wykracza poza zarzucaną jej wcześniej bezalternatywność i symetryczne odwrócenie relacji dominacji.

$\mathrm{Na}$ zakończenie warto zauważyć, że szeregi indywidualnych, przestrzenno-tożsamościowych (dys)lokacji konstruują poszczególne trajektorie, które przecinają się, zarysowując całościowe itineraria, a zarazem swego rodzaju panoramę ideologiczną współczesnego francuskiego społeczeństwa stworzoną na podstawie tożsamości poszczególnych jego reprezentantów. Ostrze krytyki wymierzone zostaje w środowiska, pomiędzy którymi nie dochodzi zwykle do mediacji: statecznych mieszczan nastoletnich neofaszystów, drugiego pokolenia emigrantów z przedmieść, przedstawicieli kleru, młodych alterglobalistów. Okazuje się również, że kwestia poczucia przynależności do określonej przestrzeni miejskiej wiąże się ze stopniem normatywizacji tożsamości jej mieszkańców. Podczas gdy ,,złote dzielnice” sprzyjają przestrzeganiu reguł inteligibilności, objęte w mniejszym stopniu reżimem panoptyzmu, dzielnice „,robotnicze” uchylają pola praktykom, które mają na celu przekroczenie lub/i naruszenie istniejących podziałów o charakterze klasowo-etniczno-płciowym. Przedmieścia ukazują natomiast konflikt społeczny i postawę buntu cechującą zamkniętych w nich wykluczonych, którzy odmawiają identyfikacji z prawomocną kulturą francuską i uczestniczą w niej na własnych zasadach. 
Clara Zgoła - absolwentka Kolegium MISH UW, eseistka i kulturoznawczyni o orientacji literaturoznawczo-antropologicznej, członkini Pracowni Studiów Miejskich, stypendystka Rządu Francuskiego, doktorantka Centre de Recherches sur les Arts et le Langage Centre National de la Recherche Scientifique-École des Hautes Études en Sciences Sociales w Paryżu oraz Zakładu Antropologii Słowa Instytutu Kultury Polskiej UW. Przygotowuje rozprawę doktorską poświęconą paryskim tożsamościom miejskim współczesnych powieściopisarzy francuskich.

\section{Dane adresowe:}

CRAL

96, bd Raspail - 75006 Paris

Tél. : +33 (0) 153635623

Fax : +33 (0)153635621

e-mail: cral@ehess.fr

Cytowanie: Clara Zgoła, Tożsamościowe (trans)lokacje bohaterów prozy Virginii Despentes na przyktadzie powieści Apocalypse bébé, „Praktyka Teoretyczna” nr 4(10)/2013, http://www.praktykateoretyczna.pl/ PT_nr10_2013_Epistemologie_feministyczne/08.Zgola.pdf (dostęp dzień miesiąc rok)

Author: Clara Zgoła - MISH UW College graduate, essayist and culture expert, a member of the Laboratory of Urban Studies, a holder of scholarship of the French Government, PhD student at the Centre de Recherches sur les Arts et le Langage Centre National de la Recherche Scientifique-Ecole Hautes Études en Sciences Sociales in Paris and Department of Anthropology of Word of the Institute of Polish Culture. She is preparing a doctoral thesis devoted to the Paris urban identities of contemporary French novelists.

Title: The Identity Trans(locations) of the protagonist of Virginia Despentes' novels. Case study of Apocalypse bébé

Summary: The article is an attempt to investigate the contemporary creativity of the French, third wave feminist, and novel writer Virginie Despentes with a focus on changes taking place in her work over the last twenty years. The first part shows the scope of the early phase of her artistic activity, which, on the main level, deals with specific issues in the French culture of the last decade of the past century, especially those taking place in relation to the reconfiguration of the French literary field in the middle of the 1990s. Of particular importance are changes in approaches of those who were excluded or marginalized because of their race/gender/class position (most often femininists), including issues of self-representation and the appearance of the trash literature trend. 
The second part of the article takes as its goal enhancing the queer aspect of Despentes' last project. It analyses Apocalypse bébé on the basis of geopoetical instrumentarium and presents information concerning the spatio-temporal dimensions of the (non)normative identities of the main characters. The authors construction of the urban chronotope of Paris and Barcelona is considered from a critical queer theory perspective, leading to the thesis of a specific utopian turn taking place in Despentes' last novel.

Keywords: trash literature, critical queer theories, sexuality and space, third wave of feminism in France, urban novel, geopoetics 


\section{recenzje i polemiki}


